\title{
Smoking cessation therapy with varenicline
}

\author{
Uma M Mohanasundaram \\ Rajinder Chitkara \\ Ganesh Krishna \\ Division of Pulmonary and Critical \\ Care Medicine, Department of \\ Medicine, Stanford University School \\ of Medicine, CA, USA
}

\begin{abstract}
Smoking cessation is the only available intervention proven to halt progression of chronic obstructive pulmonary disease (COPD). The authors discuss the current existing treatment modalities and the role of a newly approved agent, varenicline, in promotion of smoking cessation. Varenicline is a novel agent that is a centrally acting partial nicotinic acetylcholine receptor agonist. It has both agonistic and antagonistic properties that together are believed to account for reduction of craving and withdrawal as well as blocking the rewarding effects of smoking. Its targeted mechanism of action, better efficacy and tolerability makes varenicline a useful therapeutic option for smoking cessation. In this article, we discuss presently available options for smoking cessation and review the literature on efficacy of varenicline.
\end{abstract}

Keywords: smoking cessation, varenicline, nicotine, receptors, therapy, COPD

\section{Introduction}

There is significant evidence to suggest that cigarette smoking is the most important factor in the development and progression of COPD (Stang et al 2000). It is estimated that $15 \%$ of smokers worldwide will develop clinically symptomatic COPD. At the present time, a combination of pharmacological and non-pharmacological approaches seems to be effective in an attempt to control the symptoms. Beta agonists and anticholinergics decrease air-trapping and improve exercise capacity by decreasing airway smooth muscle tone and improving expiratory flow. But none of these agents have been shown to be disease-modifying therapy. Long-term oxygen therapy (LTOT) has been shown to improve survival (NOTT 1980), especially in patients with partial pressure of arterial oxygen $\left(\mathrm{PaO}_{2}\right)<60 \mathrm{mmHg}$ (Tarpu and Celli 1995). Patients undergoing comprehensive pulmonary rehabilitation program have shown to have decreased dyspnea, increased exercise capacity, improved quality of life, fewer exacerbations, lesser hospital stays and improved cardiovascular status (Lacasse 1996; Griffiths et al 2000; Guell et al 2000).

Lung volume reduction surgery (LVRS) seem to benefit patients with upper lobe disease and low exercise capacity (1-year mortality rate was 7\%). Lung transplantation improves quality of life and functional status in selected patients with advanced COPD ( $\mathrm{FEV}_{1}<35 \%$ predicted, $\mathrm{PaO}_{2}$ of $55-60 \mathrm{mmHg}$ and partial pressure of arterial carbon dioxide $\left(\mathrm{PaCO}_{2}\right)>50 \mathrm{mmHg}$ ) (Hosenpud et al 2001). Studies are underway to evaluate survival outcomes in patients with COPD following lung transplantation.

\section{Smoking cessation and its treatment modalities}

Smoking cessation remains the single most important intervention in preventing disease onset and in preserving lung function (Meinke et al 2007). Several pharmacological interventions now exist to aid smokers in cessation. Drug therapy has been increasingly relied upon to assist in smoking cessation.

The most common of these has been nicotine replacement therapy (NRT) which includes transdermal patch, gum, inhaler, nasal spray, and lozenges. A meta-analysis including 70 trials assessing NRT versus placebo at 1 year showed odds ratio (OR) of 
1.71 favoring NRT (95\% confidence interval [CI]: 1.55-1.88, $\mathrm{p} \leq 0.0001)$. The same meta-analysis evaluated 59 trials providing sufficient data to determine short-term effects of NRT on smoking cessation at 3 months. The pooled OR of these 59 trials was $1.98(95 \% \mathrm{CI}, 1.77-2.21, \mathrm{p} \leq 0.0001)$ (Wu et al 2006).

A cochrane database systemic review (Silagy et al 2004) showed that out of 103 trials comparing NRT and a placebo or non-NRT control group, OR for abstinence with NRT compared with control was 1.77 (95\% CI 1.66-1.88). The ORs for the different forms of NRT were 1.66 (95\% CI 1.52-1.81) for gum, 1.81 (95\% CI 1.63-2.02) for patches, 2.35 (95\% CI 1.63-3.38) for nasal spray, 2.14 (95\% CI 1.44-3.18) for inhaled nicotine, and 2.05 (95\% CI 1.62-2.59) for nicotine sublingual tablet/lozenge. In highly addicted smokers there was a significant benefit of $4 \mathrm{mg}$ gum compared with $2 \mathrm{mg}$ gum (OR 2.20, 95\% CI 1.85-3.25). There was weak evidence that combinations of forms of NRT are more effective. The most significant adverse events with NRT were mouth or throat irritation, skin irritation, nausea/vomiting, coughing, hiccoughs, dyspepsia, watering of eyes, headaches, palpitations, and insomnia (Wu et al 2006).

Bupropion is a weak dopamine and nor-epinephrine reuptake inhibitor. Like NRT products, bupropion has been endorsed by the US Clinical Practice Guidelines (Fiore et al 2000) as a first-line therapy. Bupropion has been shown to approximately double rates of cessation compared with placebo, and the medication is equally effective for men and women (Scharf and Shiffman 2004). The pooled OR from 12 trials evaluating the effect of bupropion on smoking cessation relative to adequate controls at 1 year was $1.56(95 \% \mathrm{CI}$ 1.10-2.21, $\mathrm{p}=0.01)$. The OR for sustained abstinence was 1.52 (11 trials, 95\% CI 1.04-2.23, p $<0.0001$ ). When the effect of bupropion on placebo at 3 months were evaluated, the OR was 2.13 (11 trials, 95\% CI 1.72-2.64, $\mathrm{p}<0.0001$ ) and for the sustained abstinence measures, the OR was 2.18 (8 trials, 95\% CI 1.67-2.86, $\mathrm{p}<0.0001$ ). The following were the adverse events observed in bupropion trials: dry mouth, insomnia, gastrointestinal upset, and constipation (Wu 2006). Its use is relatively contraindicated in smokers with a history of seizures, head trauma, heavy alcohol abuse, or anorexia.

Besides NRT products and bupropion, two medications (nortriptyline and clonidine) are endorsed by the US Clinical Practice Guidelines (Fiore et al 2000) as second-line therapies. Nortriptyline in combination with transdermal nicotine was also shown to enhance the cessation rates above levels seen with transdermal nicotine alone (Prochazka et al
2004). The tricyclic antidepressant doxepin has also been shown in a small human study to improve cessation rates (Edwards et al 1989). One study of heavy smokers who had failed in previous quit attempts found that those treated with clonidine, an alpha-2-noradrenergic agonist, had twice the rate of abstinence as those treated with placebo at the end of the 4-week treatment (Glassman et al 1988). This effect continued through the 6-month follow up. These results suggest that clonidine may be efficacious in the treatment of tobacco dependence, but the conditions under which it is most appropriately used are not well defined.

Behavioral modifications for smoking cessation include intense hypnotherapy and acupuncture. A prospective pilot trial of intensive hypnotherapy was performed involving 20 patients with multiple individual sessions ( 8 visits) over approximately 2 months. Self-reported abstinence was confirmed by a carbon monoxide concentration in expired air of $8 \mathrm{ppm}$ or less. The rates of point prevalence smoking cessation, as confirmed by carbon monoxide measurements for the intensive hypnotherapy group, was $40 \%$ at the end of treatment; $60 \%$ at 12 weeks, and $40 \%$ at 26 weeks $(\mathrm{p}<0.05)$ (Elkins et al 2006). There is no clear evidence that acupuncture, acupressure, laser therapy or electrostimulation are effective for smoking cessation (White et al 2002).

The most recent guidelines on tobacco use and dependence from the United States Public Health Service (USPHS) places a much greater emphasis on the role of assessment of readiness to change and motivating behavior change in smoking cessation (USPHS 2000). As behavioral approaches to smoking cessation became more refined, delivery systems for cessation also improved. One of the most important developments has been evolution of telephone counseling for smoking cessation. Research trials have shown increased rate of smoking cessation at one year for callers to the California Smokers Helpline who received 7 telephone counseling sessions when compared to non-counseled smokers (9.1 vs $6.9 \%$ cessation) (Zhu et al 2002). The USPHS Clinical Practical Guideline recommends multiple types of clinicians providing counseling over at least 4 sessions with a total contact time of at least 30 minutes for intensive interventions. Both counseling and pharmacotherapy are accepted means of enhancing smoking cessation among smokers. There are also several cessation aides like self-help and print materials for tobacco cessation that have been available (Lancaster and Stead 2002). Further refinement of such materials, allowed for culturally appropriate cessation aids should be delivered to various groups of tobacco users. 
Nicotine receptor partial agonists may help smokers to quit by a combination of maintaining moderate levels of dopamine to counteract withdrawal symptoms (acting as an agonist) and reducing smoking satisfaction (acting as an antagonist). Cytisine is an agonist of nicotinic receptors; in particular, it binds strongly with $\alpha_{4} \beta_{2}$ nicotinic receptors. Cytisine was developed as a treatment for tobacco dependence in Bulgaria in 1960s, and is still commercially available in central and eastern Europe. In the 1960s an early smoking cessation study with cytisine failed to exhibit robust efficacy, possibly as a result of poor absorption (Barlow and McLead 1969), and limited brain penetration (Reavill et al 1990). The Tabex trial detected a benefit of cytisine compared with placebo at 2-year follow up (OR 1.77, 95\% CI 1.30-2.40). The OR for this trial at 6 months was 2.30 (95\% CI 1.75-3.04) (Scharfenberg et al 1971). More recently, efforts to combine nicotine replacement therapy with the nicotinic antagonist mecamylamine were more successful (Rose et al 1994). These latter results of combining an agonist and antagonistessentially creating a partial agonist-suggested that an agent with an optimal partial agonist profile and physicochemical properties could provide improved relief to patients during smoking cessation attempts.

Furthermore, a recent meta-analysis looking at efficacy of cytisine in smoking cessation showed that the pooled odds ratio after 3-8 weeks in 3 placebo-controlled trials was 1.93 (95\% CI 1.21-3.06). For the two placebo-controlled double-blind trials with a longer follow-up, the pooled odds ratio after 3-6 months was 1.83 (95\% CI 1.12-2.99) (Etter 2006).

Varenicline was developed as a nicotine receptor partial agonist from cytisine, which is also a naturally occurring alkaloid compound (Cahill et al 2007). In the studies described below, varenicline was identified to be more effective than placebo, bupropion, and NRT. Despite several efforts in creating awareness of deleterious effect of smoking, it is still a major issue around the world. Even though there are several interventions available for smoking cessation, varenicline is the first drug designed to interact with a key brain receptor involved in nicotine addiction. This article covers the history of varenicline development and its pharmacodynamics, and reviews the current data on its efficacy.

\section{Neurobiology of nicotine addiction}

Nicotine, the primary psychoactive component of tobacco smoke, produces diverse neurophysiological, motivational, and behavioral effects through several brain regions and neurochemical pathways. Recent research in the fields of behavioral pharmacology, genetics, and electrophysiology is providing an increasingly integrated picture of how the brain processes the motivational effects of nicotine.

Nicotine alters the function of several CNS neurotransmitters, including dopamine (DA), noradrenaline (NA), 5hydroxytryptamine (5-HT), glutamate, gamma-aminobutryic acid (GABA), and endogenous opioid peptides (EOPs). It primarily affects the nervous system through the action of nicotinic acetylcholine receptors (nAChRs), ionotropic receptors that are widely distributed through the brain (Figure 1). The effects of $\alpha_{4}$-receptor activation have been shown to be important in dependence, including reinforcement, tolerance and sensitization (Tapper et al 2004). The dysphoric symptoms of nicotine withdrawal start to occur when the regular smoker is deprived of nicotine for at least 4-6 hours and when more nAChRs become resensitized but unstimulated by nicotine.

Many effective pharmacotherapies as mentioned earlier such as NRT, bupropion and nortriptyline appear to affect neurobiological mechanisms of nicotine dependence. They decrease nicotine withdrawal by inhibiting reuptake of dopamine and norepinephrine in the central nervous system, but without the need for a direct agonist effect (Roddy 2004). Compounds that act as $\alpha_{4} \beta_{2} \mathrm{nAChR}$ partial agonists and simultaneously block the action of nicotine (Cohen et al 2003; Coe et al 2005) offer a particularly promising new approach to helping smokers quit. This article reviews one such compound: varenicline.

\section{History of varenicline development}

Varenicline tartrate (Chantix ${ }^{\circledR}$; Pfizer), an $\alpha_{4} \beta_{2}$ nicotinic receptor partial agonist, was approved by the US FDA as an aid to smoking cessation treatment on May 11, 2006 (Niaura et al 2006). It was hypothesized that a partial agonist of $\alpha_{4} \beta_{2}$ nAChRs would lead to a moderate and sustained increase of mesolimbic dopamine levels. This might counteract the low dopamine levels that result from a lack of nicotine during attempts to quit smoking, which seem to be important in craving and withdrawal, and could therefore be crucial in leading to relapse to smoking. By also competitively binding to $\alpha_{4} \beta_{2}$ nAChRs, a partial agonist might shield a smoker from nicotine-induced increases in dopamine levels thereby preventing any events of relapse. Thus it was thought that a partial agonist of $\alpha_{4} \beta_{2}$ nAChR might aid in smoking cessation (Figure 2).

Cytisine, which is an alkaloid extracted from the seeds of Cystisus laburnum, is a partial agonist of the $\mathrm{nChR}$ 


\section{Five $\alpha 7$ subunits form an $\alpha 7$ homo-oligomeric nAChR}

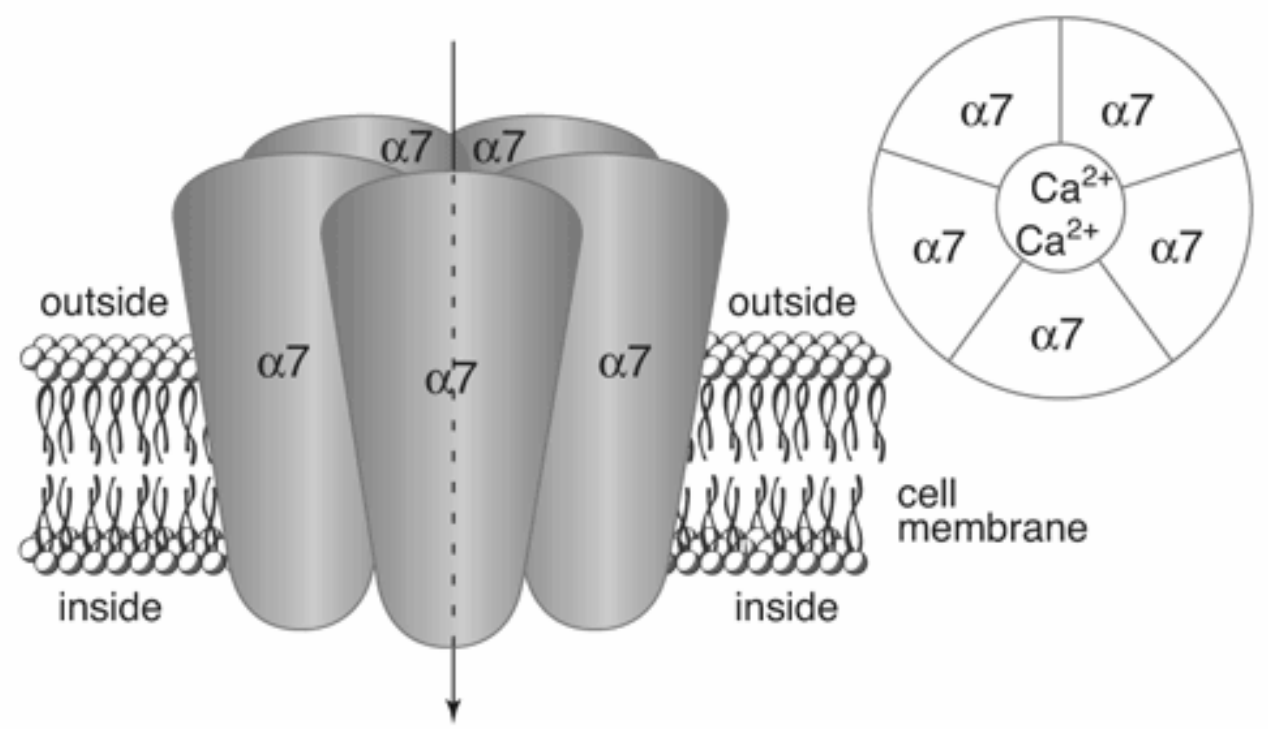

$\mathrm{Ca}^{2+}$

\section{Two $\alpha 4$ and three $\beta 2$ subunits form an $\alpha 4 \beta 2$ heteromeric $\mathrm{nAChR}$}

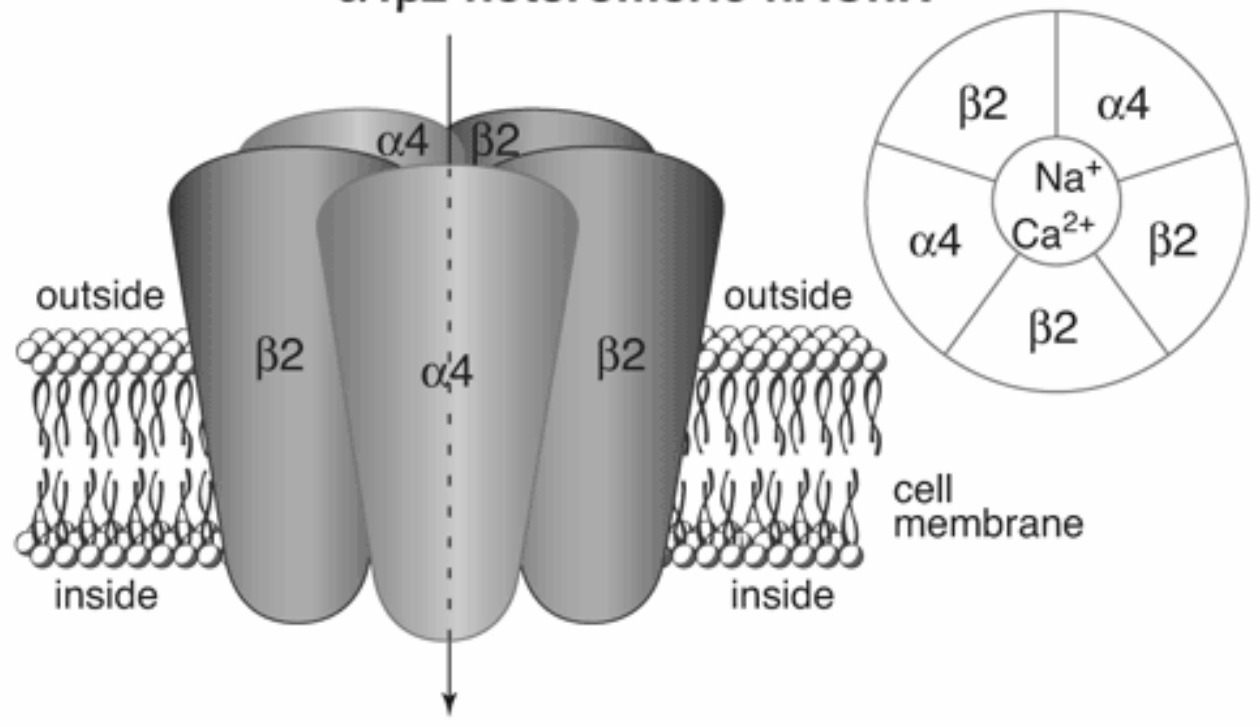

$\mathrm{Na}^{+} \mathrm{Ca}^{2+}$

Figure I Simplified structure of $\alpha 7$ and $\alpha 4 \beta 2$ nicotinic receptor located on surface of a dopamine cell body.

and antagonizes the receptor response to its endogenous neurotransmitter, acetylcholine (Papke and Heinemann 1994). Varenicline was discovered through the synthesis of a series of compounds inspired by this natural product cytisine
(Cohen et al 2003). Varenicline was found to be a selective partial agonist at the $\alpha_{4} \beta_{2}$ nAChR, displaying $30 \%-60 \%$ of the in vivo efficacy of nicotine, and also blocked the in vivo response to nicotine (Coe et al 2005). 

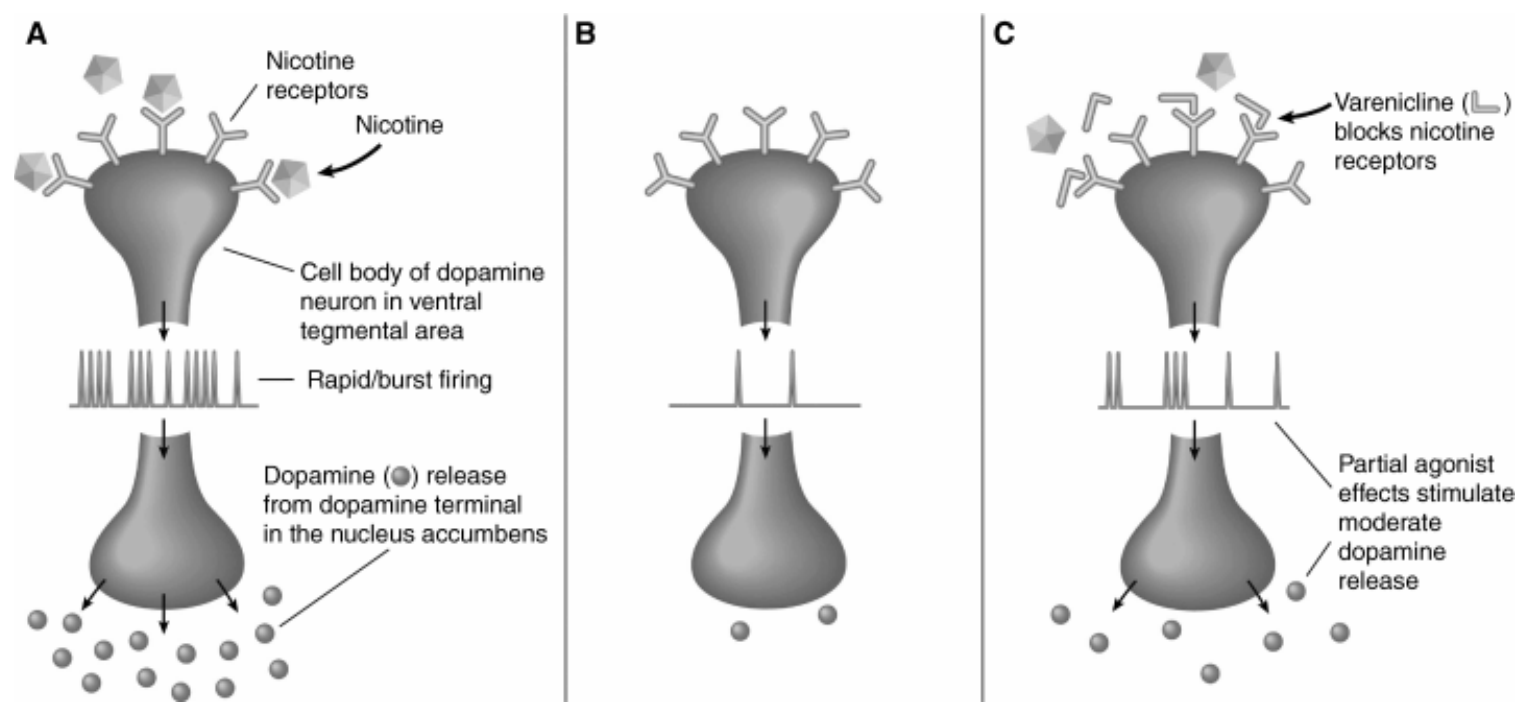

Figure 2 Effects of $(\mathbf{A})$ nicotine from cigarettes $(\mathbf{B})$ nicotine withdrawal and $(\mathbf{C})$ varenicline on nicotinic receptors and dopamine release. Reproduced with permission from Foulds J. 2006. The neurobiological basis for partial agonist treatment of nicotine dependence: varenicline. Int J Clin Pract, 60:57I-6. Copyright @ 2006 Wiley-Blackwell.

\section{Pharmacokinetics of varenicline}

Varenicline (7,8,9,10-tetrahydro-6,10-methano- $6 \mathrm{H}$ pyrazino[2,3-h][3]benzazepine) is a partial agonist selective for the $\alpha_{4} \beta_{2}$ nicotinic acetylcholine receptor subtype (Figure 3 ). This tartrate salt is highly soluble in water, with a molecular weight of 361.35 Da (Zieler-Brown and Kyle 2007).

Maximal plasma concentrations of varenicline are reached within 3-4 hours and steady-state concentration occurs within 4 days. Over the recommended dosing range, varenicline exhibits linear pharmacokinetics after single or repeated doses. In a mass balance study, absorption of varenicline was virtually complete after oral administration and systemic availability was high. Varenicline has a halflife of 24 hours and its bio-availability is not affected by

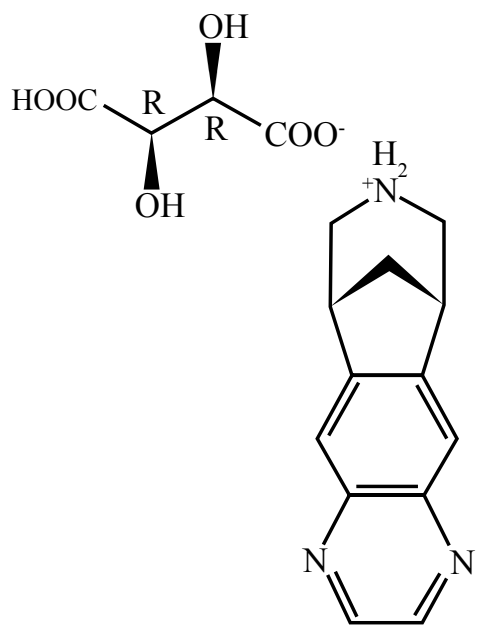

Figure 3 Varenicline tartrate (7,8,9, I0-tetrahydro-6, I0-methano-6H-pyrazino [2,3-h][3]benzazepine). food or time of administration. Varenicline exhibits linear pharmacokinetics and low plasma protein binding (20\%), regardless of a patient's age and renal function (Faessel et al 2006a). Varenicline appears to be effective for adults, regardless of age, race, gender, or smoking status. No safety data have been established for subjects under 18 years of age. This is a pregnancy class $\mathrm{C}$ drug (uncertain safety).

Varenicline is usually well tolerated after single doses up to $3.0 \mathrm{mg}$ in smokers. At doses of $10.0 \mathrm{mg}$ under fasting conditions, nausea and vomiting may occur. The underlying mechanisms responsible for the dose-related toleration and side effects are unclear at this time but are consistent with the pharmacologic actions of other nicotinic agents (Srivastava et al 1991; Perkins et al 1994). The overall mean $t_{\max }$ is about 2.9 hours in smokers and 2.6 hours in nonsmokers. Plasma varenicline concentrations decline within 10.1 hours to 25.6 hours in smokers and 8.1-30.2 hours in nonsmokers. Dose-proportional increases are observed in systemic exposure, based on $\mathrm{C}_{\max }$ and $\mathrm{AUC}_{0}$ values, after single and repeat dosing between the 1-mg and 2-mg doses of varenicline (Faessel et al 2006b). Smoking restriction does not affect the pharmacokinetics of varenicline in smokers. The pharmacokinetic disposition of varenicline in elderly smokers with normal renal function is similar to that in younger, healthy persons (Burstein et al 2006).

Varenicline's method of excretion and its metabolites were analyzed in both animal and human studies (Obach et al 2006). This study showed that the majority of drug-related material is excreted in the urine, with a substantial portion of this being represented by the parent drug rather than metabolites. In humans, greater than $90 \%$ of the recovered compound 
was unchanged varenicline, indicating that renal secretion of varenicline is a major route of drug clearance. In other work using in vitro approaches, it has been demonstrated that although varenicline can readily penetrate biological membranes by passive diffusion, it is also a substrate for human organic cation transporter 2 , a renal transport protein involved in active secretion of cationic drugs (Rollema et al 2006).

Varenicline has few metabolites. There is no readily observable difference in serum levels of these metabolites between smokers and nonsmokers. Most of orally ingested varenicline is excreted unchanged in the urine. However, there are two inactive metabolites that are observed in urine: 2-hydroxyvarenicline and varenicline $N$-carbamoylglucuronide (Obach et al 2006). These were primarily derived from reactions occurring at the alicyclic nitrogen.

\section{Review of current data on varenicline}

Several studies have shown how effective and useful varenicline is in smoking cessation. There are few landmark randomized trials on the efficacy of the nicotinic acetylcholine receptor partial agonist varenicline for achieving smoking cessation.

One trial compared the safety and efficacy of varenicline for smoking cessation with sustained-release bupoprion and placebo in a multicenter randomized, double-blind, placebo-controlled trial (Gonzales et al 2006). Participants were 1025 generally healthy smokers (10 cigarettes per day) with fewer than 3 months of smoking abstinence in the past year, 54\% male and mean age of 42.4 years. Participants were randomly assigned in a 1:1:1 ratio to receive brief counseling and varenicline titrated to $1 \mathrm{mg}$ twice per day ( $\mathrm{n}=352$ ), bupropion SR titrated to $150 \mathrm{mg}$ twice per day $(n=329)$, or placebo $(n=344)$ orally for 12 weeks, with 40 weeks of follow-up. Study completion rates were $60 \%$, $56 \%$, and $54 \%$ for varenicline, bupropion SR, and placebo, respectively. At baseline, patients smoked an average of 21 cigarettes per day and had smoked for an average of 24 years. Continuous abstinence rates from weeks 9 to 12 - the primary endpoint - were $44.0 \%$ for varenicline vs $17.7 \%$ for placebo (OR 3.85, 95\% CI 2.70-5.50, p < 0.001) and vs 29.5\% for bupropion SR (OR 1.93, 95\% CI 1.40-2.68, p < 0.001). By this measure, varenicline was superior to bupropion SR and placebo. The continuous abstinence rate for weeks 9-24 was superior for varenicline $(29.5 \%)$ vs placebo $(10.5 \%)$ (OR 3.68, 95\% CI 2.42-5.60, p < 0.001) and vs bupropion SR (20.7\%) (OR 1.63, 95\% CI 1.14-2.33, p =0.007). For weeks 9 through 52, the continuous absitence rates were
$21.9 \%$ for varenicline vs $8.4 \%$ for placebo (OR: $3.09,95 \%$ CI: $1.95-4.91, \mathrm{p}<0.001)$ and vs $16.1 \%$ for bupropion SR (OR: 1.46, 95\% CI: 0.99-2.17, p=0.057). Compared with placebo, bupropion SR and varenicline both reduced some symptoms of withdrawal, cigarette craving, and smoking reinforcement. The varenicline and placebo groups had the same rates of stopping treatment because of side effects; the rate for bupropion SR was higher.

This study also measured the effects of varenicline and bupropion SR in comparison with placebo on craving and withdrawal symptoms by The Brief Questionnaire of Smoking Urges (QSU-brief) and Minnesota Nicotine Withdrawal Scale (MNWS). As assessed by subscales of MNWS, varenicline and bupropion SR significantly reduced urge to smoke and negative affect compared with placebo $(\mathrm{p}<0.001)$. The effect size of the difference from placebo for varenicline was about twice that of bupropion SR on urge to smoke. Results from QSU-brief demonstrated that, compared with placebo, the total craving score was significantly less for both varenicline $(\mathrm{p}<0.001)$ and bupropion SR $(\mathrm{p}=0.001)$.

An important feature of this study design was the inclusion of bupropion, the only previously approved smoking cessation medication not containing nicotine, as an active compare. To prevent a negative bias against bupropion, individuals who had any prior exposure to bupropion were excluded. However, this study does not address the effects of varenicline on smokers with a history of bupropion use. Since some smokers may have taken bupropion for smoking cessation or treatment of depression, there may be limitations when interpreting these results for a broader population. This study concluded that varenicline was significantly more efficacious than placebo for smoking cessation at all time points and significantly more efficacious than bupropion SR at the end of 12 weeks of drug treatment and at 24 weeks.

The above results were confirmed by another study that determined the efficacy and safety of varenicline for smoking cessation compared with placebo or sustained-release bupropion in a randomized, double-blind, placebo-controlled trial at 14 research centers. This study enrolled 1027 healthy adult volunteers, 58\% male and mean age of 43.3 years, with a 12 -week treatment period and follow-up of smoking status to week 52 (Jorenby et al 2006). Varenicline titrated to $1 \mathrm{mg}$ twice daily $(\mathrm{n}=344)$ or bupropion SR titrated to $150 \mathrm{mg}$ twice daily $(\mathrm{n}=342)$ or placebo $(n=341)$ for 12 weeks, plus weekly brief smoking cessation counseling. During the last 4 weeks of treatment (weeks 9-12), 43.9\% of participants in the varenicline group were continuously abstinent from smoking compared with 
$17.6 \%$ in the placebo group (OR 3.85, 95\% CI 2.69-5.50, $\mathrm{p}<0.001$ ) and $29.8 \%$ in the bupropion SR group (OR $1.90,95 \%$ CI $1.38-2.62, \mathrm{p}=0.001)$. For weeks 9 through $24,29.7 \%$ of participants in the varenicline group were continuously abstinent compared with $13.2 \%$ in the placebo group (OR 2.83, 95\% CI 1.91-4.19, p < 0.001) and $20.2 \%$ in the bupropion group (OR 1.69, 95\% CI 1.19-2.42, $\mathrm{p}=0.003$ ). For weeks 9 through $52,23 \%$ of participants in the varenicline group were continuously abstinent compared with $10.3 \%$ in the placebo group (OR 2.66, 95\% CI $1.72-4.11, \mathrm{p}<0.001)$ and $14.6 \%$ in the bupropion SR group (OR 1.77, 95\% CI 1.19-2.63, p = 0.004). Treatment was discontinued due to adverse events by $10.5 \%$ of participants in the varenicline group, $12.6 \%$ in the bupropion SR group, and $7.3 \%$ in the placebo group. The most common adverse event with varenicline was nausea, which occurred in 101 participants $(29.4 \%)$.

Also in this study, in comparison with participants in the placebo group for the average over weeks 1 through 7, those in the varenicline group reported significantly less of an urge to smoke $(p<0.001)$ and had less negative affect $(p=0.001)$ as assessed by the MNWS. The results of the QSU-brief paralleled those of the MNWS with regard to craving, with both varenicline and bupropion SR reducing total craving compared with placebo ( $\mathrm{p}<0.001$ for both).

In another multicenter, double-blind, placebo-controlled, dose-ranging study, the effects of 4 varenicline dose regimens $(0.5 \mathrm{mg}$ twice daily, $1 \mathrm{mg}$ twice daily, titrated, and nontitrated) for promoting smoking cessation were evaluated (Oncken et al 2006). The study involved a longer treatment phase (12 weeks) followed by a 40 -week assessment after discontinuation of the regimen. This study included 647 healthy volunteer smokers, aged 18-65, smoking at least 10 cigarettes per day and $49.5 \%$ of them were male. The primary efficacy endpoints were the 4-week continuous quit rates for weeks 4 through 7 and 9 through 12 for the pooled (titrated and nontitrated) dose groups and abstinence was assessed by subject self-report confirmed by expired carbon monoxide. Weeks 9 through 12 continuous quit rates were greater in the 1.0 -mg group (49.4\%) and the 0.5 -mg group (44.0\%) vs placebo ( $11.6 \% ; \mathrm{p}<0.001$ vs both doses). Weeks 9 through 52 abstinence rates were greater in the $1.0-\mathrm{mg}$ group $(22.4 \% ; \mathrm{p}<0.001)$ and the 0.5 -mg group $(18.5 \%$; $\mathrm{p}<0.001)$ vs placebo (3.9\%). Varenicline was generally well tolerated, with nausea occurring in $16 \%$ to $42 \%$ of varenicline-treated subjects. Reports of nausea were lower for the titrated vs nontitrated dosing and infrequently led to medication discontinuation.
A limitation of the study is the optional follow-up study design. Subjects who abstained from smoking during weeks 9 through 12 and who did not enter the follow-up phase were counted as smokers, which may have lowered the true long-term efficacy rates (particularly in the $0.5-\mathrm{mg}$ twicedaily group). However, even if the subjects who did not enter the follow-up truly remained abstinent from smoking at 1 year, this would have underestimated the true long-term quit rate by only $4 \%$ in the 0.5 -mg twice-daily group, $1.5 \%$ in the $1.0-\mathrm{mg}$ twice-daily group, and $2.3 \%$ in the placebo group. Since approximately $90 \%$ of subjects who completed treatment continued in the follow-up phase, the analyses conducted likely represents a reasonable estimation of longterm quit rates. This study concluded that varenicline tartrate (0.5-mg and 1.0-mg doses taken twice daily for 12 weeks) significantly improved short- and long-term abstinence rates compared with placebo. In this study, too, varenicline significantly reduced the urge to smoke and withdrawal compared with placebo as measured by MNWS score.

In another randomized, multicenter, double-blind, placebo- and bupropion-controlled phase 2 (dose-ranging) study, 638 healthy smokers (18-65 years old, 10 cigarettes per day, and $48 \%$ male) were randomized to varenicline tartrate, $0.3 \mathrm{mg}$ once daily $(\mathrm{n}=128), 1.0 \mathrm{mg}$ once daily ( $\mathrm{n}=128)$, or $1.0 \mathrm{mg}$ twice daily $(\mathrm{n}=127)$, for 6 weeks plus placebo for 1 week; to $150 \mathrm{mg}$ sustained-release bupropion hydrochloride twice daily $(n=128)$ for 7 weeks; or to placebo $(n=127)$ for 7 weeks. Forty-four per cent of the subjects had previously used transdermal nicotine replacement therapy (Nides et al 2006). During the treatment phase, the continuous quit rates for any 4 weeks were significantly higher for varenicline tartrate, $1.0 \mathrm{mg}$ twice daily $(48.0 \%$, OR $4.71,95 \%$ CI $2.60-8.53, \mathrm{p}<0.001)$ and $1.0 \mathrm{mg}$ once daily $(37.3 \%$, OR 2.97, 95\% CI 1.63-5.40, p < 0.001), than for placebo (17.1\%). The bupropion quit rate was 33.3\% (OR $2.53,95 \%$ CI $1.38-4.63, \mathrm{p}=0.002$ ) vs placebo. The carbon monoxide-confirmed continuous quit rates from week 4-52 were significantly higher in the varenicline tartrate, $1.0-\mathrm{mg}$ twice-daily, group compared with the placebo group (14.4\% vs $4.9 \%, p=0.002)$. The bupropion rate was $6.3 \%(\mathrm{p}=0.60)$ vs placebo. Discontinuation owing to treatment-emergent adverse events was $15.9 \%$ for bupropion, $11.2 \%$ to $14.3 \%$ for varenicline, and $9.8 \%$ for placebo. This study demonstrated superior efficacy of varenicline for short- and long-term (up to 1 year) smoking cessation compared with placebo.

When compared with placebo, varenicline $1 \mathrm{mg}$ twice daily significantly reduced craving and several aspects of smoking reinforcement. Although subjects were still smoking 
during the first week of treatment, only $1 \mathrm{mg}$ twice daily of varenicline was effective in reducing the reinforcing effects of smoking as measured by the smoking satisfaction scale.

A limitation of this study was the inclusion of subjects who had previously failed bupropion therapy - about $13 \%-20 \%$ had failed bupropion therapy for smoking cessation before study enrollment. The distribution of these patients among treatment groups was not reported. Theoretically, inclusion of these nonresponders to bupropion therapy could lead to a lower abstinence rate in the bupropion group, and make varenicline seem more efficacious in comparison. The above-mentioned four studies could be generalized to a cohort of middle-aged healthy male smokers who are willing to quit.

One of the landmark trials addressed the issue of preventing relapse, after quitting (Tonstad et al 2006). Although $50 \%$ of smokers can achieve abstinence for several weeks, $50 \%-60 \%$ of quitters resumed smoking within 1 year. Out of 2416 screened patients, 1928 were assigned to receive open-label varenicline for 12 weeks. They then randomly assigned those who had been abstinent during the 12 th week (1210 successful quitters, $49 \%$ male, mean age 45 years) to receive either varenicline or placebo for 12 weeks of doubleblind treatment. Regardless of smoking status, everyone then continued in a nontreatment phase for an additional 28 weeks, for a total of 52 weeks. The dose of varenicline was $1.0 \mathrm{mg}$ twice daily, double the dose of the other two trials. The primary endpoint was reported abstinence from any nicotine product during the double-blind treatment phase, as confirmed by negative results on an exhaled carbon monoxide test.

A total of 1210 of the 1928 patients (62.8\%) were abstinent during the 12 th week of the open-label treatment phase and eligible for randomization. The carbon monoxide-confirmed continuous abstinence rate was significantly higher for the varenicline group than for the placebo group for weeks $13-24$ (70.5\% vs 49.6\%, OR 2.48, 95\% CI 1.95-3.16, $\mathrm{p}<0.001)$ as well as for weeks $13-52$ (43.6\% vs 36.9\%, OR $1.34,95 \%$ CI 1.06-1.69, $\mathrm{p}=0.02)$. The authors concluded that extended use of varenicline helps recent ex-smokers to maintain their abstinence and prevent relapse. Varenicline is the first drug aimed at smoking cessation to demonstrate a significant long-term effect. However, a temporary acceleration of the rate of relapse occurred in the varenicline group after the withdrawal of medication. This study also proved that with 1 year follow up, more than $50 \%$ of participants in both varenicline and placebo groups returned to smoking. Discontinuation of varenicline in participants randomized to placebo at week 12 was followed by a mean urge-to-smoke value that was small and only modestly higher than that of double blinded varenicline participants. The above-mentioned clinical trials are summarized in Table 1.

More recently, the safety of long-term varenicline administration for smoking cessation was assessed (Williams et al 2007). In this randomized, double-blind, multicenter trial, eligible adult smokers (18-75 years) who smoked an average of $\geq 10$ cigarettes/day were randomized to either varenicline $1 \mathrm{mg}$ twice daily or placebo for 52 weeks. Subjects made weekly clinic visits until week 8 , and then every 4 weeks until week 52, with a follow-up visit at week 53. The target quit date was the morning of the week 1 clinic visit. Brief counseling was provided at each visit, and vital signs, adverse events (AEs), and smoking status were documented. A total of 251 subjects were randomized to varenicline and 126 to placebo. Approximately half of the subjects in each arm completed the study (53.8\% varenicline; $46.8 \%$ placebo). AEs were noted in $96.4 \%$ of treatment arm and $82.5 \%$ in the placebo arm. Common varenicline-associated AEs were nausea (40.2\%), abnormal dreams (22.7\%), and insomnia (19.1\%). AEs leading to discontinuation of varenicline treatment included nausea (7.6\%), insomnia (3.2\%), and abnormal dreams (2.4\%). A single varenicline-related serious AE, bilateral subcapsular cataracts, was observed. At week 52, 7-day point prevalence abstinence rates were $36.7 \%$ (varenicline) and $7.9 \%$ (placebo) (Table 2). The authors concluded that varenicline $1 \mathrm{mg}$ twice daily can be safely administered for up to 1 year. Varenicline was also a more effective smoking cessation aid than placebo throughout the study, supporting both its short- (12-week) and long-term (52-week) efficacy.

A systematic review and meta-analysis to evaluate effectiveness of smoking cessation therapies was conducted (Wu et al 2006). In this study, the authors discussed that varenicline was superior to placebo at 1 year ( 4 randomized controlled trials (RCTs), OR 2.96, 95\% CI 2.12-4.12, $\mathrm{p} \leq 0.0001$ ) and also at approximately 3 months (OR 3.75, 95\% CI 2.65-5.30). Three RCTs evaluated the effectiveness of varenicline versus bupropion at 1 year (OR 1.58, 95\% CI 1.22-2.05) and at approximately 3 months (OR 1.61, 95\% CI 1.16-2.21). Using indirect comparisons, varenicline was superior to NRT when compared to placebo controls (OR $1.66,95 \% \mathrm{CI} 1.17-2.36, \mathrm{p}=0.004)$ or to all controls at 1 year (OR 1.73, 95\% CI 1.22-2.45, p = 0.001). They concluded that NRT, bupropion, and varenicline all provide therapeutic effects in assisting with smoking cessation. Direct and indirect comparisons identify a hierarchy of effectiveness (Wu et al 2006). 
Table I Summary of clinical trials

\begin{tabular}{|c|c|c|c|c|}
\hline Reference & Design & Sample (N) & Treatment & Abstinence rate \\
\hline Gonzales (2006) & $\begin{array}{l}\text { Double-blind, comparative; } 12 \text { wks } \\
\text { treatment, } 52 \text { wks post-treatment }\end{array}$ & $\begin{array}{l}352 \\
329 \\
344\end{array}$ & $\begin{array}{l}\text { Buproprion SR } 150 \mathrm{mg} \text { twice } \\
\text { daily } \\
\text { Placebo }\end{array}$ & $\begin{array}{l}\text { Weeks 9-12 } \\
\text { Varenicline 44\% } \\
\text { Buproprion SR 30\% } \\
\text { Placebo I7\% } \\
\text { Weeks 9-24 } \\
\text { Varenicline 29\% } \\
\text { Buproprion SR 21\% } \\
\text { Placebo II\% } \\
\text { Weeks 9-52 } \\
\text { Varenicline 22\% } \\
\text { Buproprion SR 16\% } \\
\text { Placebo 8\% }\end{array}$ \\
\hline Jorenby (2006) & $\begin{array}{l}\text { Double-blind, comparative; } 12 \text { wks } \\
\text { treatment, } 52 \text { wks post-treatment }\end{array}$ & $\begin{array}{l}344 \\
342 \\
341\end{array}$ & $\begin{array}{l}\text { Varenicline I mg twice daily } \\
\text { Buproprion SR I50 mg twice } \\
\text { daily } \\
\text { Placebo }\end{array}$ & $\begin{array}{l}\text { Weeks } 9-12 \\
\text { Varenicline 44\% } \\
\text { Buproprion SR 30\% } \\
\text { Placebo I7\% } \\
\text { Weeks 9-24 } \\
\text { Varenicline 29\% } \\
\text { Buproprion SR 20\% } \\
\text { Placebo I3\% } \\
\text { Weeks 9-52 } \\
\text { Varenicline 23\% } \\
\text { Buproprion SR 14\% } \\
\text { Placebo I0\% }\end{array}$ \\
\hline Ocken (2006) & $\begin{array}{l}\text { Double-blind, phase } 2 \text {, multicenter, } \\
\text { placebo controlled. } 12 \text { wks treatment, } \\
40 \text { wks post-treatment }\end{array}$ & 129 & $\begin{array}{l}\text { Varenicline } 0.5 \mathrm{mg} \text { nontitrated } \\
\text { (twice daily for } 12 \text { wks) } \\
\text { Varenicline } 0.5 \mathrm{mg} \text { titrated } \\
\text { (wk I once daily, wks } 2-12 \\
\text { twice daily) } \\
\text { Varenicline I mg nontitrated } \\
\text { (twice daily for } 12 \text { wks) } \\
\text { Varenicline I mg titrated } \\
\text { ( } 0.5 \mathrm{mg} \text { once daily for } 3 \text { days, } \\
0.5 \mathrm{mg} \text { twice daily for } 4 \text { days, } \\
\text { I mg twice daily wks } 2-12 \text { ) } \\
\text { Placebo twice daily for } 12 \text { wks }\end{array}$ & $\begin{array}{l}\text { Weeks } 4-7 \\
\text { Varenicline } 0.5 \text { mg twice daily } 36.3 \% \\
\text { Varenicline I mg twice daily } 39.8 \% \\
\text { Placebo } 10.9 \% \\
\text { Weeks } 9-12 \\
\text { Varenicline } 0.5 \text { mg twice daily } 44 \% \\
\text { Varenicline I mg twice daily } 49.4 \% \\
\text { Placebo II.6\% } \\
\text { Weeks } 9-52 \\
\text { Varenicline } 0.5 \text { mg twice daily } 18.5 \% \\
\text { Varenicline I mg twice daily } 22.4 \% \\
\text { Placebo } 3.9 \%\end{array}$ \\
\hline Nides (2006) & $\begin{array}{l}\text { Double-blind, phase } 2 \text {, multicenter, } \\
\text { placebo controlled. } 7 \text { wk treatment } \\
\text { ( } 6 \mathrm{wk}+\text { I wk placebo or } 7 \text { wks } \\
\text { buproprion/ placebo), 8-52 wks } \\
\text { post-treatment }\end{array}$ & $\begin{array}{l}128 \\
128 \\
127 \\
128 \\
127\end{array}$ & $\begin{array}{l}\text { Varenicline } 0.3 \mathrm{mg} \text { once daily } \\
\text { Varenicline I mg once daily } \\
\text { Varenicline I mg twice daily } \\
\text { Buproprion SR I50 mg twice } \\
\text { daily } \\
\text { Placebo }\end{array}$ & $\begin{array}{l}\text { Weeks } 0-4 \\
\text { Varenicline I mg twice daily } 48 \% \\
\text { Varenicline I mg once daily } 37.3 \% \\
\text { Buproprion SR } 33.3 \% \\
\text { Placebo I7.I\% } \\
\text { Weeks 4-52 } \\
\text { Varenicline I mg twice daily } 14.4 \% \\
\text { Varenicline I mg once daily } 37.3 \% \\
\text { Buproprion SR } 6.3 \% \\
\text { Placebo } 4.9 \%\end{array}$ \\
\hline Tonstad (2006) & $\begin{array}{l}\text { Double-blind phase, long-term } \\
\text { abstinence, open-label, I } 2 \text { wk } \\
\text { treatment, I } 3-52 \text { wks post-treatment }\end{array}$ & $\begin{array}{l}603 \\
607\end{array}$ & $\begin{array}{l}\text { Varenicline I mg twice daily } \\
\text { Placebo }\end{array}$ & $\begin{array}{l}\text { Weeks I3-24 } \\
\text { Varenicline } 70 \% \\
\text { Placebo } 50 \% \\
\text { Weeks I3-52 } \\
\text { Varenicline } 44 \% \\
\text { Placebo } 39 \%\end{array}$ \\
\hline
\end{tabular}

Abbreviations: wk, week; SR, sustained release. 
Table 2 Long-term safety of varenicline

\begin{tabular}{llllll}
\hline Reference & Design & Sample (N) & Treatment & Adverse events & Abstinence rate at wk 52 \\
\hline Williams (2006) & $\begin{array}{l}\text { Double-blind, } \\
\text { phase-2, multicenter, } \\
\text { placebo controlled } \\
\text { 52-wk follow up }\end{array}$ & $25 I$ & Varenicline I mg twice & Nausea 40.2\% & Varenicline 36.7\% \\
daily & 126 & Placebo & P.9\% \\
& & dreams 22.7\% & \\
\hline
\end{tabular}

Abbreviation: wk, week.

The literature reviewed here suggests that varenicline shows efficacy comparable to that of bupropion SR and superior to that placebo. No safety or efficacy data have been established for varenicline use in combination with other smoking cessation medications.

\section{Dosage and administration}

Varenicline has FDA approval as monotherapy. Varenicline is supplied orally in 2 strengths: $0.5 \mathrm{mg}$ and $1.0 \mathrm{mg}$. Varenicline treatment should be initiated 1 week prior to a quit date. The titration schedule consists of a 1-week lead-in phase followed by a dose of $1 \mathrm{mg}$ twice daily. The gradual increase in titration is recommended to limit the occurrence of nausea. A 12-week course of treatment is recommended, with an additional 12 weeks included to ensure long-term abstinence. Successive attempts are recommended for those who relapse or fail therapy. The titration schedule is as follows: days 1-3, $0.5 \mathrm{mg}$ daily; days 4-7, $0.5 \mathrm{mg}$ twice daily; and, starting on day $8,1.0 \mathrm{mg}$ twice daily. A maximum dosage of $0.5 \mathrm{mg}$ daily is recommended for patients undergoing hemodialysis for end-stage renal disease (Chantix: Package insert).

The estimated 12-month employer cost savings (US\$) per nonsmoking employee were $\$ 540.60$ for varenicline, $\$ 269.80$ for bupropion SR generic, $\$ 150.80$ for bupropion SR brand, and $\$ 81.80$ for placebo (Jackson et al 2007). Varenicline was more cost beneficial than placebo, which had quit rates of $16.9 \%$ or less. The quit rate with varenicline would have to be $\leq 16.9 \%$ to lose cost benefit over bupropion SR generic. The authors, hence, conclude that the economic benefit of varenicline is better than that of bupropion, despite the increased initial cost of varenicline. The initial month's blister pack is estimated to cost $\$ 100$, while refills of the blister packs are to range between $\$ 90$ and $\$ 100$. Total cost associated with a 12 -week course of therapy is estimated to be $\$ 300$ (ZielerBrown and Kyle 2007). This is in comparison with NRTs that cost about $\$ 4-\$ 15$ per day, nicotine inhaler that costs $\$ 45$ per package, and bupropion that costs $\$ 2$ per day.

Dosage adjustments are required for patients with renal insufficiency but not in hepatic insufficiency (Molander et al
2001). Drug-drug interactions have been evaluated, with no clinically significant findings shown with varenicine or co-inhibitors of the human organic cation transporter, which mediates renal secretion of varenicline. Substrates such as warfarin, digoxin, cimetidine, metformin, bupropion, and transdermal nicotine do not alter pharmacokinetic parameters when coadministered with varenicline. In vitro studies do not demonstrate a cytochrome P450 enzyme effect.

\section{Safety and tolerability}

In phase 2 and 3 placebo-controlled studies, the treatment discontinuation rate due to adverse events in patients dosed with $1 \mathrm{mg}$ twice daily was $12 \%$ for varenicline compared with $10 \%$ for placebo in studies of 3 months' treatment. In this group, the discontinuation rates for the most common adverse events in varenicline-treated patients were: nausea ( $3 \% \mathrm{vs}$ $0.5 \%$ for placebo), headache ( $0.6 \%$ vs $0.9 \%$ for placebo), insomnia ( $1.2 \%$ vs $1.1 \%$ for placebo), and abnormal dreams ( $0.3 \%$ vs $0.2 \%$ for placebo).

All the studies described above showed that the most common adverse event associated with varenicline treatment is nausea. For patients treated to the maximum recommended dose of $1 \mathrm{mg}$ twice daily following initial dosage titration, the incidence of nausea was $30 \%$ compared with $10 \%$ in patients taking a comparable placebo regimen. In patients taking varenicline $0.5 \mathrm{mg}$ twice daily following initial titration, the incidence was $16 \%$ compared with $11 \%$ for placebo. Nausea was generally described as mild or moderate and often transient.

However, for some subjects, it was persistent throughout the treatment period (Chantix: Package insert). Table 3 shows comparison of different varenicline studies with nausea being the most frequent adverse effects.

In a recent meta-analysis (Wu et al 2006), the following adverse effects were reported significantly more often among the varenicline group compared with placebo group: nausea ( 4 trials, $\mathrm{n}=2506$, OR $3.17,95 \%$ CI $2.35-4.29$, $\mathrm{p}<0.0001$ ), flatulence ( 2 trials, $\mathrm{n}=1323$, OR $2.04,95 \% \mathrm{CI}$ $1.16-3.57, \mathrm{p}=0.01$ ) and, constipation ( 4 trials, $\mathrm{n}=2506$, OR $2.57,95 \%$ CI $1.21-5.45, \mathrm{p}<0.0001)$. Other severe events 
Table 3 Most frequent adverse effect: nausea (Cahill et al 2007)

\begin{tabular}{llll}
\hline Studies & $\begin{array}{l}\text { Placebo } \mathbf{n} / \mathbf{N} \\
\text { (\%) }\end{array}$ & $\begin{array}{l}\text { Varenicline } \mathbf{n} / \mathbf{N} \\
(\%)\end{array}$ & $\begin{array}{l}\text { Bupropion } \mathbf{n} / \mathbf{N} \\
\text { (\%) }\end{array}$ \\
\hline Gonzales 2006 & $29 / 344(8.4)$ & $98 / 349(28.1)$ & $41 / 329(12.5)$ \\
Jorenby 2006 & $33 / 340(9.7)$ & $101 / 343(29.4)$ & $25 / 340(7.4)$ \\
Nides 2006 & $23 / 123(18.7)$ & $65 / 125(52)$ & $27 / 126(21.4)$ \\
Oncken 2006 & I9/I2I (14.9) & $97 / 253(38.3)$ & \\
& & $45 / 129(34.9)$ titrated \\
& & $52 / 124(41.9)$ & \\
& & non-titrated & \\
Reeves 2006 & I0/126(7.9) & I0I/25I (40.2)
\end{tabular}

Abbreviations: $n$, number of subjects with nausea; $N$, total number of subjects in the study.

included atrial fibrillation (Gonzales et al 2006), pneumonia, and stroke (Oncken et al 2006). There is no apparent effect of varenicline on clinical laboratory assessments, vital signs (blood pressure and heart rate), QTc, or ECG morphology (Faessel et al 2006b).

\section{Expert opinion and future trends}

To date all studies demonstrate that varenicline is associated with higher smoking cessation rates than placebo and may produce better cessation rates than bupropion. Varenicline represents a third class of drug with a different mechanism of action than either NRT or bupropion. Its novel mechanism offers another approach to assist patients with smoking cessation. Different forms of NRT and bupropion still remains the first-line of treatment for smoking cessation, primarily because of over-the-counter availability and also some safety concerns surrounding varenicline. Varenicline has FDA approval as monotherapy, with further studies needed evaluating combination therapy. In the future, Pfizer plans to conduct a study to determine the multiple-dose pharmacokinetics of varenicline in young subjects in order to determine the appropriate doses for efficacy and safety evaluations in adolescent smokers aged 12 through 16 . They plan to establish if there is an age group (or weight group) in whom varenicline is poorly tolerated that its utility as an aid to smoking cessation should not be evaluated. Also, there are plans to conduct a prospective epidemiologic cohort study in pregnant women who are smokers and who are exposed to varenicline at the time of conception or any time during pregnancy. This information will be used to assess the potential risk to the fetus and/or live born infants.

One of the primary symptoms of smoking cessation is depression and it is hypothesized that smokers may be increasing central dopamine levels by reducing monoamine oxidase inhibitor activity (Ascher et al 1995). By this mechanism bupropion may be helpful to maintain central levels of dopamine through the process of cessation, although its effectiveness has been identified to be independent of symptoms of depression (Hurt et al 1997). The partial agonists at nicotinic acetylcholine receptor like varenicline could stimulate the release of sufficient dopamine to reduce craving and withdrawal while simultaneously acting as a partial antagonist by blocking the binding and consequent reinforcing effects of nicotine (Gonzales et al 2006). Varenicline has been a unique central acting agent that opens the door to future studies. One of the drawbacks of varenicline is that its efficacy is not assessed in combination with other therapies.

Other treatments that are currently being studied are rimonabant, a cannabinoid receptor agonist that appears to partially mediate central nervous system effects of nicotine in rodents (Cohen et al 2002). Also, several nicotine vaccines are under investigation. These vaccines are believed to induce antibodies against the nicotine molecule preventing the drug from reaching neural receptors that produce the effects normally associated with smoking (Pentel et al 2000).

Systematic implementation of effective cessation interventions should be a major focus of public health, with greater emphasis placed on the dual role of the clinician and the health care delivery system. Finally, reducing the worldwide tobacco burden will require complementary efforts to reduce initiation and promote cessation.

\section{References}

Ai-Ping C, Lee KH, Lim TK. 2005. In-hospital and 5-year mortality of patients treated in the ICU for acute exacerbation of COPD: a retrospective study. Chest, 128:518-24.

Andreoli M, Tessari M, Pilla M, et al. 2003. Selective antagonism at dopamine D3 receptors prevents nicotine-triggered relapse to nicotineseeking behavior. Neuropsychopharmacology, 28:1272-80.

Ascher JA, Cole JO, Colin JN, et al. 1995. Bupropion: a review of its mechanism of antidepressant activity. $J$ Clin Psychiatry, 56:395-401.

Barlow RB, McLead LJ. 1969. Some studies on cytisine and its methylated derivatives. BrJ Pharmacol, 35:161-74.

Berry MJ, Adair NE, Rejeski, WJ. 2006. Use of peak oxygen consumption in predicting physical function and quality of life in COPD patients. Chest, 129:1516.

Burstein AH, Fullerton T, Clark DJ, et al. 2006. Pharmacokinetics, Safety, and Tolerability after Single and Multiple Oral Doses of Varenicline in Elderly Smokers. J Clin Pharmacol, 46:1234-40.

Cahill K, Stead LF, Lancaster T. 2007. Nicotine receptor partial agonists for smoking cessation. Cochrane Database of Systematic Reviews 1, CD006103 DOI: 10.1002/14651858.CDC006103.pub2

Celli BR, Cote CG, Marin JM, et al. 2004. The body-mass index, airflow obstruction, dyspnea, and exercise capacity index in chronic obstructive pulmonary disease. $N$ Engl J Med, 350:1005.

Chantix package insert; Pfizer. http://www.pfizer.com/files/products/ uspi_chantix.pdf

Coe JW, Brooks PR, Vetelino MG, et al. 2005. Varenicline: an $\alpha 4 \beta 2$ nicotinic receptor partial agonist for smoking cessation. J Med Chem, 48:3474-7. 
Cohen C, Perrault G, Voltz C, et al. 2002. SR141716, a central cannabinoid (CB (1)) receptor antagonist, blocks the motivational and dopaminereleasing effects of nicotine in rats. Behav Pharmacol, 13:451-63.

Cohen C, Bergis OE, Galli F, et al. 2003. SSR591813, a novel selective and partial $\alpha 4 \beta 2$ nicotinic receptor agonist with potential as an aid to smoking cessation. J Pharmacol Exp Ther, 306:407-20.

Collins AC, Luo Y, Selvaag S. 1994. Sensitivity to nicotine and brain nicotinic receptors are altered by chronic nicotine and mecamylamine infusion. J Pharmacol Exp Ther, 271:125-33.

Cousins MS, Stamat HM, de Wit H. 2001. Effects of a single dose of baclofen on self-reported subjective effects and tobacco smoking. Nicotine Tob Res, 3:123-9.

Dahl M, Vestbo J, Lange P, et al. 2007. C-reactive protein as a predictor of prognosis in chronic obstructive pulmonary disease. Am J Respir Crit Care Med, 175:250.

Decker MW, Meyer MD, Sullivan JP. 2001. The therapeutic potential of nicotinic acetylcholine receptor agonists for pain control. Expert Opin Investig Drugs, 10:1819-30.

Diaz PT, King MA, Pacht ER, et al. 2000. Increased susceptibility to pulmonary emphysema among HIV-seropositive smokers. Ann Intern Med, 132:369.

Edwards NB, Murphy JK, Downs AD, et al. 1989. Doxepin as an adjunct to smoking cessation: a double-blind pilot study. Am J Psychiatry, 146:373-6.

Elkins G, Marcus J, Bates J, et al. 2006. Intensive hypnotherapy for smoking cessation: a prospective study. Int J Clin Exp Hypn, 54:303-15.

Etter JF. 2006. Cytisine for smoking cessation: a literature review and a meta-analysis. Arch Intern Med, 166:1553-9.

Faessel HM, Smith BJ, Gibbs MA, et al. 2006a. Single-dose pharmacokinetics of varenicline, a selective nicotinic receptor partial agonist, in healthy smokers and nonsmokers. J Clin Pharmacol, 46:991-8.

Faessel HM, Gibbs MA, Clark DJ, et al. 2006b. Multiple-dose pharmacokinetics of the selective nicotinic receptor partial agonist, varenicline, in healthy smokers. J Clin Pharmacol, 46:1439-48.

Fattore L, Cossu G, Martellotta MC. 2002. Baclofen antagonizes intravenous self-administration of nicotine in mice and rats. Alcohol Alcohol, 32:495-8.

Finlay GA, Russell KJ, Mcmahon KJ, et al. 1997. Elevated levels of matrix metalloproteinases on bronchoalveolar lavage fluid in emphysematous patients. Thorax, 52:502-6.

Fiore MC, Bailey WC, Cohen SJ, et al. 2000. Treating Tobacco Use and Dependence. Clinical Practice Guideline. Rockville, MD. US Department of Health and Human Services, Public Health Service.

Fishman A, Martinez F, Naunheim K, et al. 2003. A randomized trial comparing lung-volume-reduction surgery with medical therapy for severe emphysema. N Eng J Med, 348:2059-73.

Foster TS, Miller JD, Marton JP, et al. 2006. Assessment of the economic burden of COPD in the U.S.: a review and synthesis of the literature. COPD, 3:211-8.

Foulds J. 2006. The neurobiological basis for partial agonist treatment of nicotine dependence: varenicline. Int J Clin Pract, 60:571-6.

Fowler JS, Volkow ND, Wang GJ, et al. 1996. Inhibition of monoamine oxidase B in the brains of smokers. Nature, 379:733-6.

Fowler JS, Volkow ND, Wang GJ, et al. 1996. Brain monoamine oxidase A: inhibition by cigarette smoke. Proc Natl Acad Sci USA, 93:14065-9.

Glassman AH, Stetner F, Walsh BT, et al. 1988. Heavy smokers, smoking cessation, and clonidine: results of a double-blind, randomized trial. JAMA, 259:2863-6.

Gonzales D, Rennard SI, Nides M, et al. 2006. Varenicline, an alpha4beta2 nicotinic acetylcholine receptor partial agonist, vs sustained-release bupropion and placebo for smoking cessation: a randomized controlled trial. JAMA, 296:47-55.

Griffiths TL, Burr ML, Campbell IA, et al. 2000. Results at 1 year of outpatient multidisciplinary pulmonary rehabilitation: a randomized controlled trial. Lancet, 355:362-8.

Guell R, Casan P, Belda J, et al. 2000. Long term effects of outpatient rehabilitation of COPD: A randomized trial. Chest, 117:976-83.
Hattotuwa KL, Gizycki MJ, Ansari TW, et al. 2002. The effects of inhaled fluticasone on airway inflammation in chronic obstructive pulmonary disease: a double-blind, placebo-controlled biopsy study. Am J Resp Crit Care Med, 165:1592-96.

Hosenpud JD, Bennett LE, Keck BM, et al. 2001. The registry of the International Society for Heart and Lung Transplantation: eighteenth official report - 2001. J Heart Lung Transplant, 20:909-31.

Hospers JJ, Postma DS, Rijcken B, et al. 2000. Histamine airway hyperresponsiveness and mortality from chronic obstructive pulmonary disease: a cohort study. Lancet, 356:13-13.

Hurt RD, Sachs DP, Glover ED, et al. 1997. A comparison of sustainedrelease bupropion and placebo for smoking cessation. $N$ Engl J Med, 337:1195-202.

Jackson KC, Nahoopii R, Said Q, et al. 2007. An employer-based cost-benefit analysis of a novel pharmacotherapy agent for smoking cessation. $J$ Occup Environ Med, 49:453-60.

Jorenby DE, Leischow SJ, Nides MA, et al. 1999. A controlled trial of sustained-release bupropion, a nicotine patch, or both for smoking cessation. N Engl J Med, 340:685-91.

Jorenby DE, Hays JT, Rigotti NA, et al. 2006. Efficacy of varenicline, an alpha4beta2 nicotinic acetylcholine receptor partial agonist, vs placebo or sustained-release bupropion for smoking cessation: a randomized controlled trial. JAMA, 296:56-63.

Joseph AM, Norman SM, Ferry LH, et al. 1996. The safety of transdermal nicotine as an aid to smoking cessation in patients with cardiac disease. N Engl J Med, 335:1792-8.

Keane J, Gershon S, Wise RP, et al. 2001. Tuberculosis associated with infiliximab, a tumor necrosis factor $\alpha$ neutralizing agent. $N$ Eng J Med, 345:1098-104.

Krishnan-Sarin, S, Meandzija B, O'Malley S. 2003. Nicotine patch and naltrexone for smoking cessation: a preliminary study. Nicotine Tob Res, 5:851-7.

Lacasse Y, Wong E, Guyatt GH, et al. 1996. Meta-analysis of respiratory rehabilitation in chronic obstructive pulmonary disease. Lancet, 348:1115-9.

Lancaster T, Stead LF. 2002. Self-help interventions for smoking cessation. Cochrane Database Syst Rev, CD001118.

Mahler DA, Huang S, Tabrizi M, et al. 2004. Efficacy and safety of a monoclonal antibody recognizing interleukin-8 in COPD: a pilot study. Chest, 126:926-34.

Meinke L, Chitkara R, Krishna G. 2007. Advances in the management of chronic obstructive pulmonary disease. Expert Opin Pharmacother, 8:23-37.

Molander L, Hansson A, Lunell E. 2001. Pharmacokinetics of nicotine in healthy elderly people. Clin Pharmacol Ther, 69:57-65.

Niaura R, Jones C, Kirkpatrick P. 2006. Varenicline. Nat Rev Drug Discov, 5:537-8.

Nides M, Oncken C, Gonzales D, et al. 2006. Smoking cessation with varenicline, a selective [alpha]4[beta] 2 nicotinic receptor partial agonist: results from a 7-week, randomized, placebo- and bupropion-controlled trial with 1-year follow-up. Arch Intern Med, 166:1561-8.

NOTT: Nocturnal oxygen therapy trial group. 1980. Continuous or nocturnal oxygen therapy in hypoxemic chronic obstructive lung disease: a clinical trial. Ann Intern Med, 93:391-8.

Obach RS, Reed-Hagen AE, Krueger SS, et al. 2006. Metabolism and disposition of varenicline, a selective alpha4beta2 acetylcholine receptor partial agonist, in vivo and in vitro. Drug Metab Disp, 34:121-30.

Oncken C, Gonzales D, Nides M, et al. 2006. Efficacy and safety of the novel selective nicotinic acetylcholine receptor partial agonist, varenicline, for smoking cessation. Arch Intern Med, 166:1571-7.

Perkins KA, Grobe JE, Fonte C, et al. 1994. Chronic and acute tolerance to subjective, behavioral and cardiovascular effects of nicotine in humans. J Pharmacol Exp Ther, 270:628-38.

Papke RL, Heinemann SF. 1994. Partial agonist properties of cytisine on neuronal nicotinic receptors containing the 2 subunit. Mol Pharmacol, $45: 142-9$. 
Paterson NE, Semenova S, Gasparini F, et al. 2003. The mGluR5 antagonist MPEP decreased nicotine self-administration in rats and mice. Psychopharmacology (Berl), 167:257-64.

Pentel PR, Malin DH, Ennifar S, et al. 2000. A nicotine conjugate vaccine reduces nicotine distribution to brain and attenuates its behavioral and cardiovascular effects in rats. Pharmacol Biochem Behav, 65:191-8.

Picciotto MR, Zoli M, Rimondini R, et al. 1998. Acetylcholine receptors containing the $\beta 2$ subunit are involved in the reinforcing properties of nicotine. Nature, 391:173-7.

Prochazka AV, Kick S, Steinbrunn C, et al. 2004. A randomized trial of nortriptyline combined with transdermal nicotine for smoking cessation. Arch Intern Med, 164:2229-33.

Rasmussen K, Calligaro DO, Czachura JF, et al. 2000. The novel 5-hydroxytryptamine 1A antagonist LY426965: effects on nicotine withdrawal and interactions with fluoxetine. J Pharmacol Exp Ther, 294:688-700.

Ray R, Schnoll RA, Lerman C. 2007. Pharmacogenetics and smoking cessation with nicotine replacement therapy. CNS Drugs, 21:525-33.

RCP: Royal College of Physicians. 2000. Nicotine addiction in Britain: A Report of the Tobacco Advisory Group of the Royal College of Physicians. London.

Reavill C, Walther B, Stolerman IP, et al. 1990. Behavioral and pharmacokinetic studies on nicotine, cytisine and lobeline. Neuropharmacology, 29:619-24.

Reeves K, Watsky E, Williams K, et al. 2006. The safety of varenicline taken for 52 weeks for smoking cessation. Society for Research on Nicotine and Tobacco 12th Annual Conference Orlando, FL, USA.

Roddy E. 2004. Bupropion and other non-nicotine pharmacotherapies. BMJ, 328: 509-11.

Rollema H, Chambers LK, Coe JW, et al. 2006. Pharmacological profile of the $\alpha_{4} \beta_{2}$ nicotinic acetylcholine receptor partial agonist varenicline, an effective smoking cessation aid. Neuropharmocology, 52:985-94

Rose JE, Behm FM, Westman EC. 1994. Mecamylamine combined with nicotine skin patch facilitates smoking cessation beyond nicotine patch treatment alone. Clin Pharmacol Ther, 56:86-99.

Scharf D, Shiffman S. 2004. Are there gender differences in smoking cessation, with and without bupropion? Pooled and meta-analyses of clinical trials of Bupropion SR. Addiction, 99:1462-9.

Scharfenberg G, Benndorf S, Kempe G. 1971. Cytisine (Tabex®) as a treatment for smoking cessation. Das Deutsche Gesundheitwesen, 26:463-5.

Seneff MG, Wagner DP, Wagner RP, et al. 1995. Hospital and 1-year survival of patients admitted to intensive care units with acute exacerbation of chronic obstructive pulmonary disease. JAMA, 274:1852-7.

Shiffman S, Johnston JA, Khayrallah M, et al. 2000. The effect of bupropion on nicotine crav-ing and withdrawal. Psychopharmacology, $148: 33-40$
Silagy C, Lancaster T, Stead L, et al. 2004. Nicotine replacement therapy for smoking cessation. Cochrane Database Syst Rev, 3:CD000146.

Srivastava ED, Russell MAH, Feyerabend C, et al. 1991. Sensitivity and tolerance to nicotine in smokers and nonsmokers. Psychopharmacology, 105:63-8.

Stang P, Lydick E, Silberman C, et al. 2000. The prevalence of COPD: using smoking rates to estimate disease frequency in general population. Chest, 117:354S-9S.

Sutherland G, Stapleton JA, Russell MA. 1995. Naltrexone, smoking behavior and cigarette withdrawal. Psychopharmacology (Berl), 120:418-25.

Tapper AR, McKinney SL, Nashmi R, et al. 2004. Nicotine activation of $\alpha 4^{*}$ receptors: sufficient for reward, tolerance, and sensitization. Science, 306:1029-32.

Tarpu SP, Celli BR. 1995. Long term oxygen therapy. N Engl J Med, $333: 710-4$.

Tonstad S, Tonnesen P, Hajek P, et al. 2006. Effect of maintenance therapy with varenicline on smoking cessation: a randomized controlled trial JAMA, 296:64-71.

Trakada G, Marangos M, Spiropoulos K. 2001. Mechanisms of endothelin-1 elevation in chronic obstructive pulmonary disease patients with nocturnal oxyhemoglobin desaturation. Respiration, 68:134-9.

USPHS: US Public Health Service report. The Tobacco Use and Dependence Clinical Practice Guideline Panel, Staff, and Consortium Representatives. 2000. A clinical practice guideline for treating tobacco use and dependence. JAMA, 83:3244-54.

White AR, Rampes H, Ernst E. 2002. Acupuncture for smoking cessation. Cochrane Database Syst Rev, 2:CD000009.

Wilkinson TM, Patel IS, Wilks M, et al. 2003. Airway bacterial load and FEV1 decline in patients with chronic obstructive pulmonary disease. Am J Respir Crit Care Med, 167:1090.

Williams KE, Reeves KR, Billing CB Jr, et al. 2007. A double-blind study evaluating the long-term safety of varenicline for smoking cessation. Curr Med Res Opin, 23:793-801.

Wu P, Wilson K, Dimoulas P, et al. 2006. Effectiveness of smoking cessation therapies: a systematic review and meta-analysis. BMC Public Health, 6:300.

Zhu SH, Anderson CM, Tedeschi GJ, et al. 2002. Evidence of real-world effectiveness of a telephone quitline for smokers. $N \mathrm{Engl} \mathrm{J} \mathrm{Med}$, 347:1087-93.

Zieler-Brown L, Kyle J. 2007. Oral varenicline for smoking cessation. Ann Pharmacother, 41:95-9. 
